Supporting Information

\title{
Stereoselective Synthesis of P-Chiral Phosphorus Compounds From $N$-t-Butoxycarbonyl Amino Acids
}

\author{
William H. Hersh, ${ }^{* \dagger}$ Lauren Klein, ${ }^{\dagger}$ and Louis J. Todaro ${ }^{\S}$
}

'Department of Chemistry and Biochemistry, Queens College and the Graduate Center of the City University of New York, Flushing, NY 11367-1597, and ${ }^{\S}$ Department of Chemistry, Hunter College, New York, NY 10021

william_hersh@qc.edu

Table of Contents

\begin{tabular}{|l|l|l|l|}
\hline Page & Content & Page & Content \\
\hline S1 & General & S7 & IR of 7. \\
\hline S2 & Synthesis of compound 7 & S8 & ${ }^{1}$ H NMR of 8 \\
\hline S2 & Synthesis of compound 8 & S9 & ${ }^{31}$ P NMR of 8. \\
\hline S2 & Information on compound 9 & S10 & ${ }^{13}$ C NMR of 8. \\
\hline S2 & $\begin{array}{l}\text { Information on variable } \\
\text { temperature NMR spectra }\end{array}$ & S11 & IR of 8. \\
\hline S3 & $\begin{array}{l}\text { Table 1. Comparison of Bond } \\
\text { aengths }(\AA) \text { and Angles }\left({ }^{\circ}\right) \text { in } \mathbf{2}\end{array}$ & S12 & ${ }^{1}$ H NMR of 9 \\
\hline S3 & $\begin{array}{l}\text { Table 2. Variable temperature } \\
\text { NMR data. }\end{array}$ & S13 & ${ }^{31}$ P NMR of 9. \\
\hline S4 & ${ }^{1}$ H NMR of 7 & S14 & ${ }^{13}$ C NMR of 9. \\
\hline S5 & ${ }^{31}$ P NMR of 7. & S15 & IR of 9. \\
\hline S6 & ${ }^{13}$ C NMR of 7. & & \\
\hline
\end{tabular}

General . All manipulations of air-sensitive compounds were carried out in an inert atmosphere glovebox under recirculating nitrogen. ${ }^{1} \mathrm{H},{ }^{13} \mathrm{C}$, and ${ }^{31} \mathrm{P}$ NMR spectra were recorded at 400, 100, and $160 \mathrm{MHz}$, respectively; chemical shifts are reported relative to TMS for ${ }^{1} \mathrm{H}$ and ${ }^{13} \mathrm{C}$ $\mathrm{NMR}$, and to external $85 \% \mathrm{H}_{3} \mathrm{PO}_{4}$ at $0 \mathrm{ppm}$ (positive values downfield) for ${ }^{31} \mathrm{P} \mathrm{NMR}$. Infrared spectra were obtained in $0.1 \mathrm{~mm} \mathrm{NaCl}$ solution cells on a computer-controlled FT-IR spectrometer. Optical rotations were measured at room temperature in a $1.0 \mathrm{dm}$ cell.

All solvents were treated under nitrogen. Benzene and tetrahydrofuran were distilled from sodium benzophenone ketyl. Hexane was purified by washing successively with 5\% nitric acid in sulfuric acid, water, sodium bicarbonate solution, and water, and then dried over calcium chloride and distilled from $n$-butyllithium in hexane. $\mathrm{CDCl}_{3}$ was vacuum-transferred from phosphorus pentoxide. Silica gel (200-400 mesh) was dried for several hours under vacuum while heating with a heat gun and was transferred under vacuum into the glovebox. $\mathrm{PhPCl}_{2}$ was degassed prior to use, $\mathrm{NEt}_{3}$ was distilled from $\mathrm{CaH}_{2}$, and $t$-Boc amino acids were used as received. 
(2R, 4S)-3-tert-butyloxycarbonyl-5-oxo-2-phenyl-1,3,2-oxazaphospholidine (7). In the glovebox, $t$-Boc glycine $(2.00 \mathrm{~g}, 11.2 \mathrm{mmol})$ was dissolved in $3 \mathrm{~mL}$ of THF, and the solvent was removed under vacuum in order to remove any water that might be present. It was then redissolved in $40 \mathrm{~mL}$ of THF, $\mathrm{NEt}_{3}(2.36 \mathrm{~g}, 24.4 \mathrm{mmol})$ was added in $\sim 1 \mathrm{~mL}$ of THF, and then a solution of $2.18 \mathrm{~g}(12.2 \mathrm{mmol})$ of $\mathrm{PhPCl}_{2}$ in $10 \mathrm{~mL}$ of THF was added dropwise over 5 min to the stirred solution, immediately giving a white precipitate. An aliquot taken for ${ }^{31} \mathrm{P} N \mathrm{NR}$ showed complete conversion to product, but stirring was still allowed to continue overnight. The mixture was filtered through a short column of silica gel (filling $30 \mathrm{~mL}$ of a $60 \mathrm{~mL}$ fritted funnel), washed with THF, and the solvent removed to give $2.12 \mathrm{~g}$ crude product (66\% yield) that was close to spectroscopically pure. This was crystallized by dissolving in $2 \mathrm{~mL}$ of $\mathrm{CH}_{2} \mathrm{Cl}_{2}$, cooling at $-30{ }^{\circ} \mathrm{C}$, layering on an equal volume of hexanes, and cooling overnight to give $0.78 \mathrm{~g}$ of fine white crystals; a second crop of $0.55 \mathrm{~g}$ was obtained in the same way (41\% total yield). IR $\left(\mathrm{CHCl}_{3}\right): 1797(\mathrm{~s}), 1713(\mathrm{~s}) \mathrm{cm}^{-1} ;{ }^{1} \mathrm{H} \mathrm{NMR}\left(\mathrm{CDCl}_{3}\right): \delta 7.50(\mathrm{~m}, 5 \mathrm{H}), 4.23\left(\mathrm{br} \mathrm{dd},{ }^{3} J_{\mathrm{PH}}=4.9\right.$ $\left.\mathrm{Hz},{ }^{2} J_{\mathrm{HH}}=17.8 \mathrm{~Hz}, 1 \mathrm{H}\right), 3.95\left(\mathrm{dd},{ }^{3} J_{\mathrm{PH}}=1.4 \mathrm{~Hz},{ }^{2} J_{\mathrm{HH}}=17.8 \mathrm{~Hz}, 1 \mathrm{H}\right) 1.45(\mathrm{~s}, 9 \mathrm{H}) .{ }^{31} \mathrm{P} \mathrm{NMR}$ $\left(\mathrm{CDCl}_{3}\right): 135.2 \mathrm{ppm} .{ }^{13} \mathrm{C} \mathrm{NMR}\left(\mathrm{CDCl}_{3}\right): 170.8$ (br s), 152.4 (br s), 139.37 (d, $\left.J_{\mathrm{PC}}=43.3 \mathrm{~Hz}\right)$, 132.2, $129.2\left(\mathrm{~d}, J_{\mathrm{PC}}=23.8 \mathrm{~Hz}\right), 129.0\left(\mathrm{~d}, J_{\mathrm{PC}}=6.3 \mathrm{~Hz}\right), 83.1,42.8(\mathrm{br} \mathrm{s}), 28.2 \mathrm{ppm}$. Anal. Calcd for $\mathrm{C}_{13} \mathrm{H}_{16} \mathrm{NO}_{4} \mathrm{P}:$ C, 55.52; H, 5.73; N, 4.98. Found: C, 55.79; H, 5.91; N, 4.78.

(2R, 4S)-3-tert-butyloxycarbonyl-4-methyl-5-oxo-2-phenyl-1,3,2-oxazaphospholidine (8). In the glovebox, $t$-Boc alanine $(2.00 \mathrm{~g}, 10.6 \mathrm{mmol})$ was dissolved in $3 \mathrm{~mL}$ of THF, and the solvent was removed under vacuum in order to remove any water that might be present. It was then redissolved in $40 \mathrm{~mL}$ of THF, $\mathrm{NEt}_{3}(2.11 \mathrm{~g}, 20.8 \mathrm{mmol})$ was added in $\sim 1 \mathrm{~mL}$ of THF, and then a solution of $1.89 \mathrm{~g}(10.6 \mathrm{mmol})$ of $\mathrm{PhPCl}_{2}$ in $10 \mathrm{~mL}$ of THF was added dropwise over 5 min to the stirred solution, immediately giving a white precipitate. The mixture was filtered through a short column of silica gel (filling $30 \mathrm{~mL}$ of a $60 \mathrm{~mL}$ fritted funnel), washed with THF, and the solvent removed to give $2.66 \mathrm{~g}$ of spectroscopically pure crude product ( $85 \%$ yield). This was dissolved in $\sim 2 \mathrm{~mL}$ of ether, cooled to $-30^{\circ} \mathrm{C}$, and then $2 \mathrm{ml}$ of hexanes was layed on and the mixture allowed to stand at $-30{ }^{\circ} \mathrm{C}$ overnight to give $0.68 \mathrm{~g}$ of fine white crystals; a second crop of $0.45 \mathrm{~g}$ was obtained in the same way (36\% total yield). $[\alpha]^{26}{ }_{\mathrm{D}}=372.8(\mathrm{c}=2.485$, $\left.\mathrm{C}_{6} \mathrm{H}_{6}\right)$; IR $\left(\mathrm{CHCl}_{3}\right): 1787(\mathrm{~s}), 1712(\mathrm{~s}), 1678(\mathrm{~m}) \mathrm{cm}^{-1} ;{ }^{1} \mathrm{H} \mathrm{NMR}\left(\mathrm{CDCl}_{3}\right): \delta 7.55(\mathrm{~m}, 3 \mathrm{H}), 7.47$ $(\mathrm{m}, 2 \mathrm{H}), 4.43(\mathrm{br} \mathrm{s}, 1 \mathrm{H}), 1.70\left(\mathrm{~d},{ }^{3} J_{\mathrm{HH}}=6.8 \mathrm{~Hz}, 3 \mathrm{H}\right), 1.29(\mathrm{~s}, 9 \mathrm{H}) .{ }^{31} \mathrm{P} \mathrm{NMR}\left(\mathrm{CDCl}_{3}\right): 134.6$ ppm. ${ }^{13} \mathrm{C} \mathrm{NMR}\left(\mathrm{CDCl}_{3}\right): 173.5$ (br s), 152.1 (br s), $139.8\left(\mathrm{~d}, J_{\mathrm{PC}}=49.1 \mathrm{~Hz}\right), 132.6,130.1\left(\mathrm{~d}, J_{\mathrm{PC}}\right.$ $=26.1 \mathrm{~Hz}), 128.9\left(\mathrm{~d}, J_{\mathrm{PC}}=7.1 \mathrm{~Hz}\right), 82.9,50.4,28.0,18.3 \mathrm{ppm}$. Anal. Calcd for $\mathrm{C}_{14} \mathrm{H}_{18} \mathrm{NO}_{4} \mathrm{P}: \mathrm{C}$, 56.95; H, 6.14; N, 4.74. Found: C, 56.84; H, 6.19; N, 4.79.

\section{(2R, 4S)-3-tert-butyloxycarbonyl-4-isopropyl-5-oxo-2-phenyl-1,3,2-}

oxazaphospholidine (9). The synthetic details may be found in the published Note. Details of the structure determination may be found in the cif file, and comparison of selected bond lengths and angles to cis-3-toluenesulfonyl-5-oxo-2-phenyl-1,3,2-oxazaphospholidine (2) may be found in Table 1.

Variable temperature NMR spectra. Data collected as described in the published Note may be found in Table 2. 
Table 1. Comparison of Bond Lengths $(\AA)$ and Angles $\left({ }^{\circ}\right)$ in 2 and 9.

2

9

\begin{tabular}{lll}
\hline $\mathrm{P}-\mathrm{O}_{\text {ring }}$ & $1.678(3)$ & $1.643(6)$ \\
$\mathrm{P}-\mathrm{N}$ & $1.744(4)$ & $1.753(6)$ \\
$\mathrm{P}-\mathrm{Ph}$ & $1.824(5)$ & $1.831(8)$ \\
$\mathrm{O}_{\text {ring }}-\mathrm{C}$ & $1.367(6)$ & $1.372(9)$ \\
${\mathrm{N}-\mathrm{C}_{\text {ring }}}$ & $1.475(6)$ & $1.439(9)$ \\
$\mathrm{O}_{\text {ring }}-\mathrm{P}-\mathrm{N}$ & $90.9(2)$ & $88.7(3)$ \\
$\mathrm{O}_{\text {ring }}-\mathrm{P}-\mathrm{Ph}$ & $101.1(2)$ & $100.5(3)$ \\
$\mathrm{N}-\mathrm{P}-\mathrm{Ph}$ & $99.9(2)$ & $102.0(3)$ \\
$\mathrm{P}-\mathrm{N}-\mathrm{C}_{\text {ring }}$ & $112.5(3)$ & $116.14)$ \\
$\mathrm{P}-\mathrm{N}-\mathrm{R}^{a}$ & $118.4(2)$ & $120.1(5)$ \\
$\mathrm{C}_{\text {ring }}-\mathrm{N}-\mathrm{R}^{a}$ & $120.0(3)$ & $122.7(6)$ \\
$\Sigma \mathrm{N}^{b}$ & 350.9 & 358.9 \\
\hline
\end{tabular}

${ }^{a} \mathrm{R}^{\prime}=$ non-ring substituent on nitrogen. ${ }^{b}$ sum of the three angles at nitrogen.

Table 2. Variable temperature NMR data

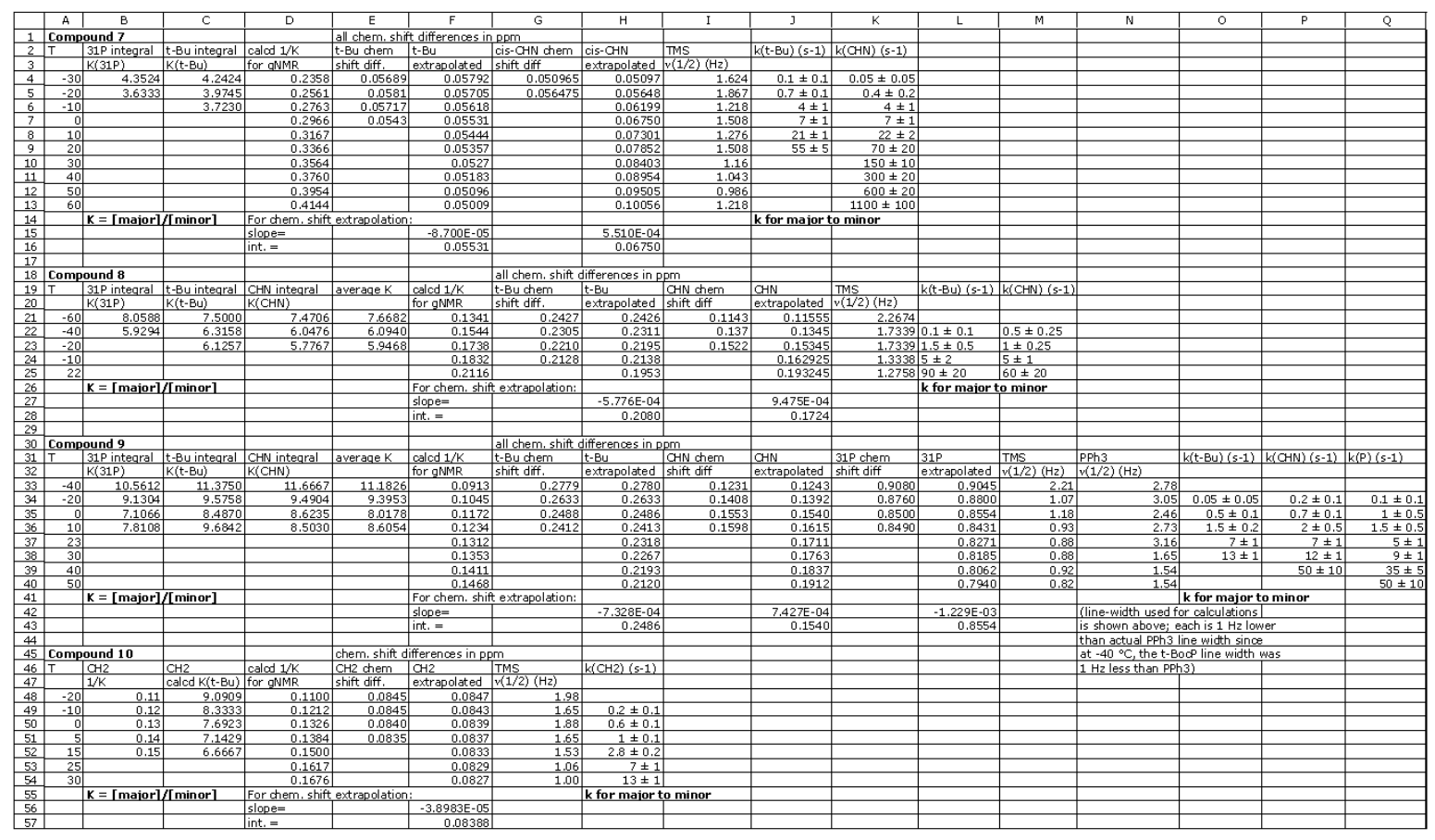




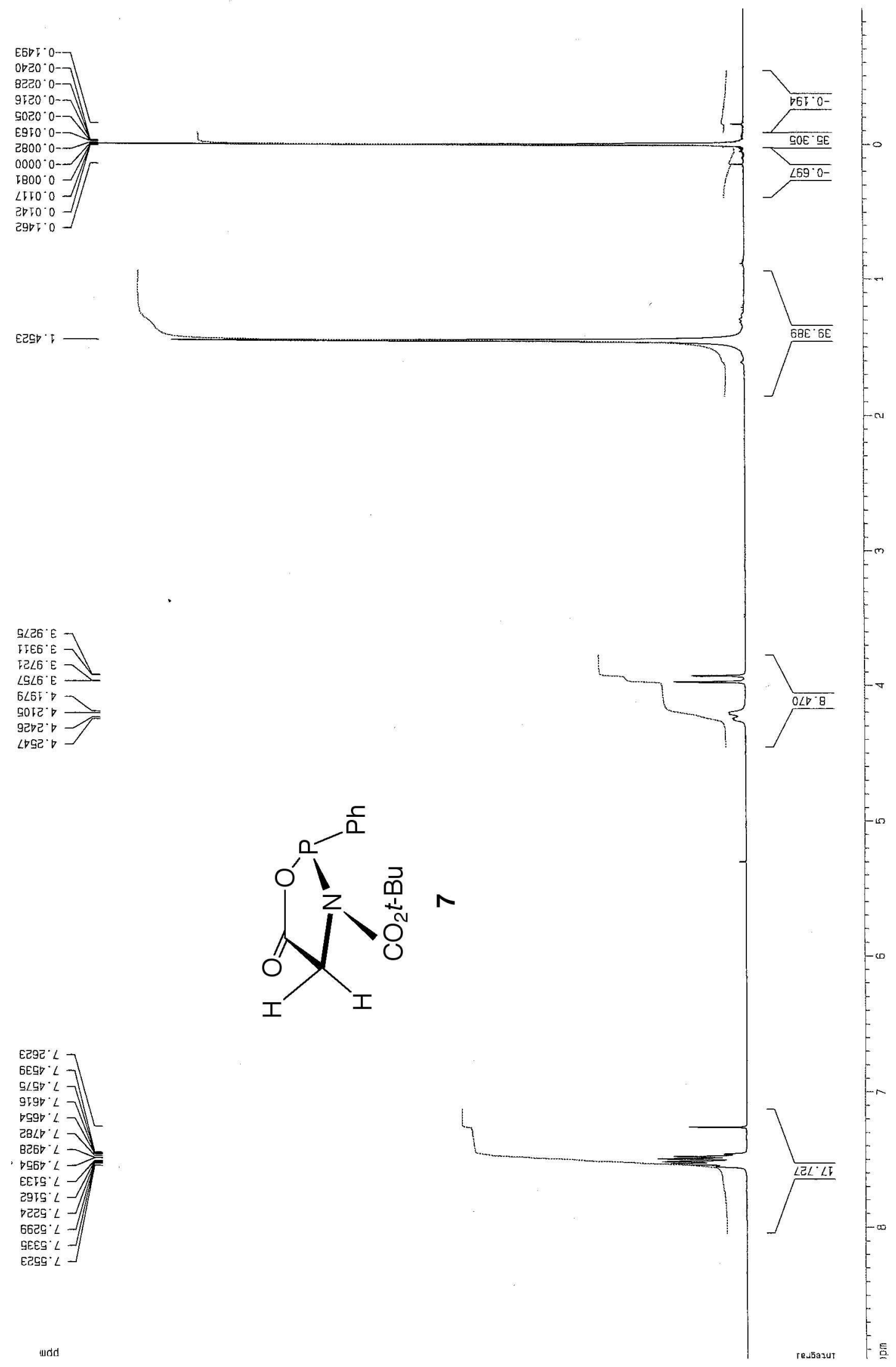




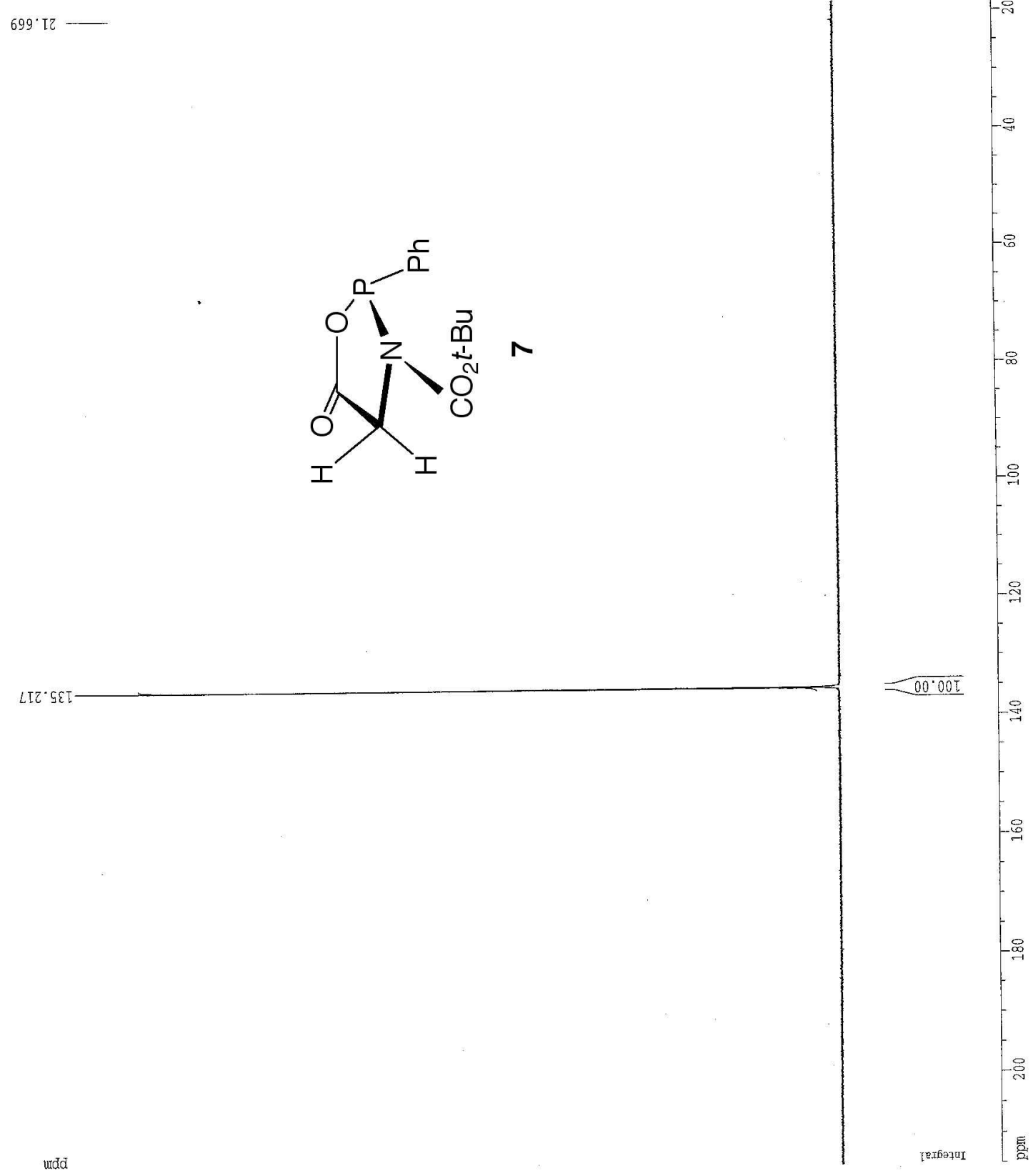




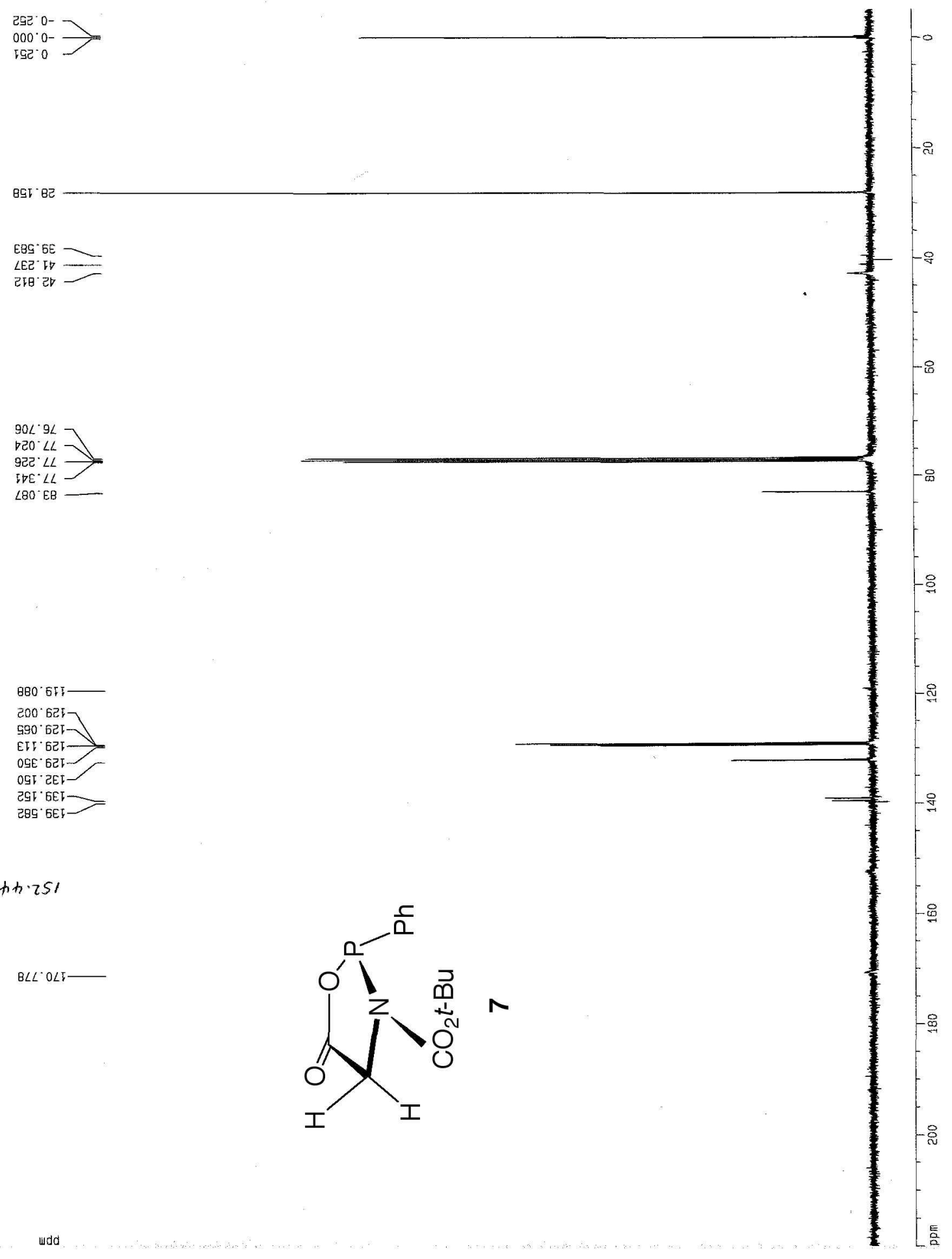




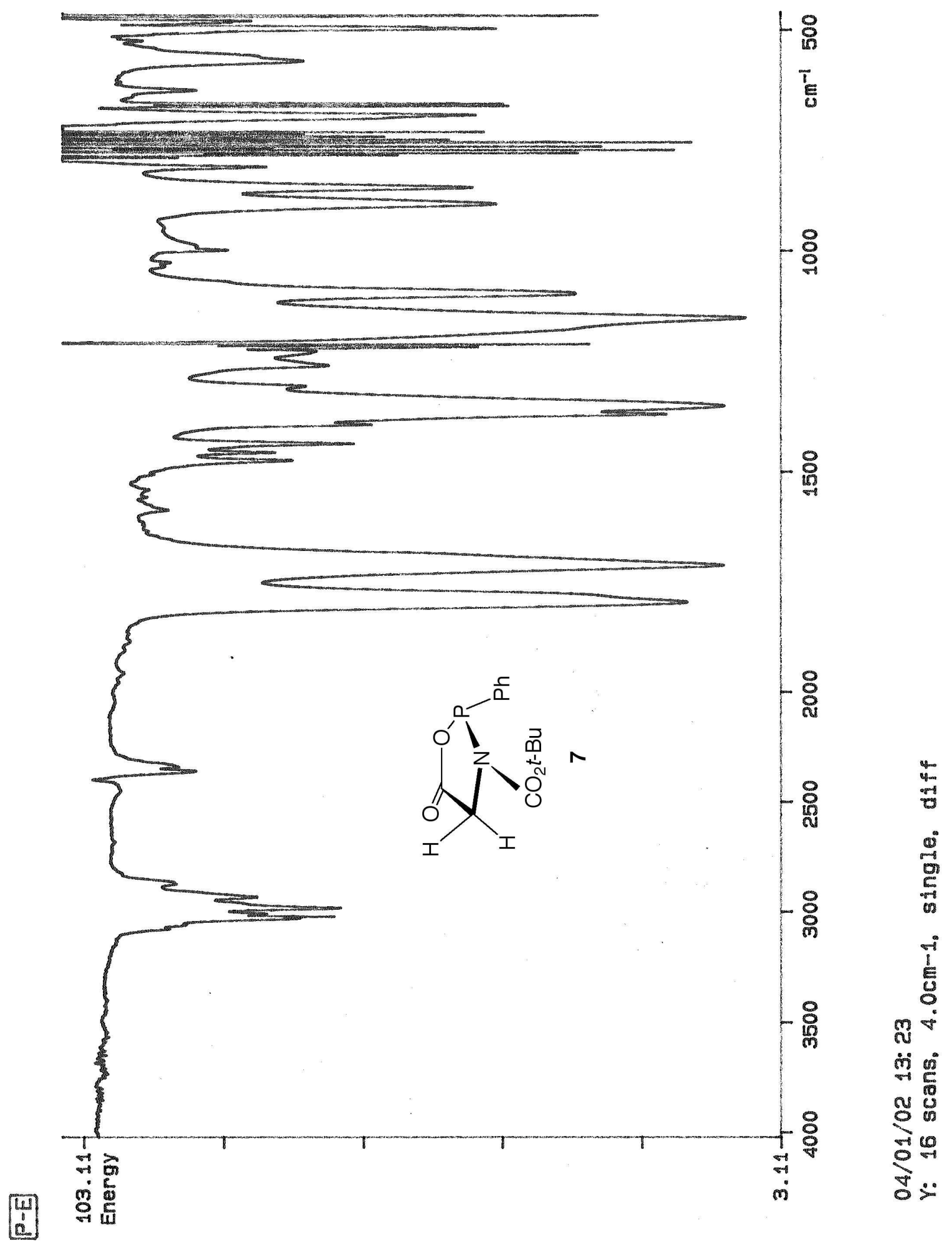




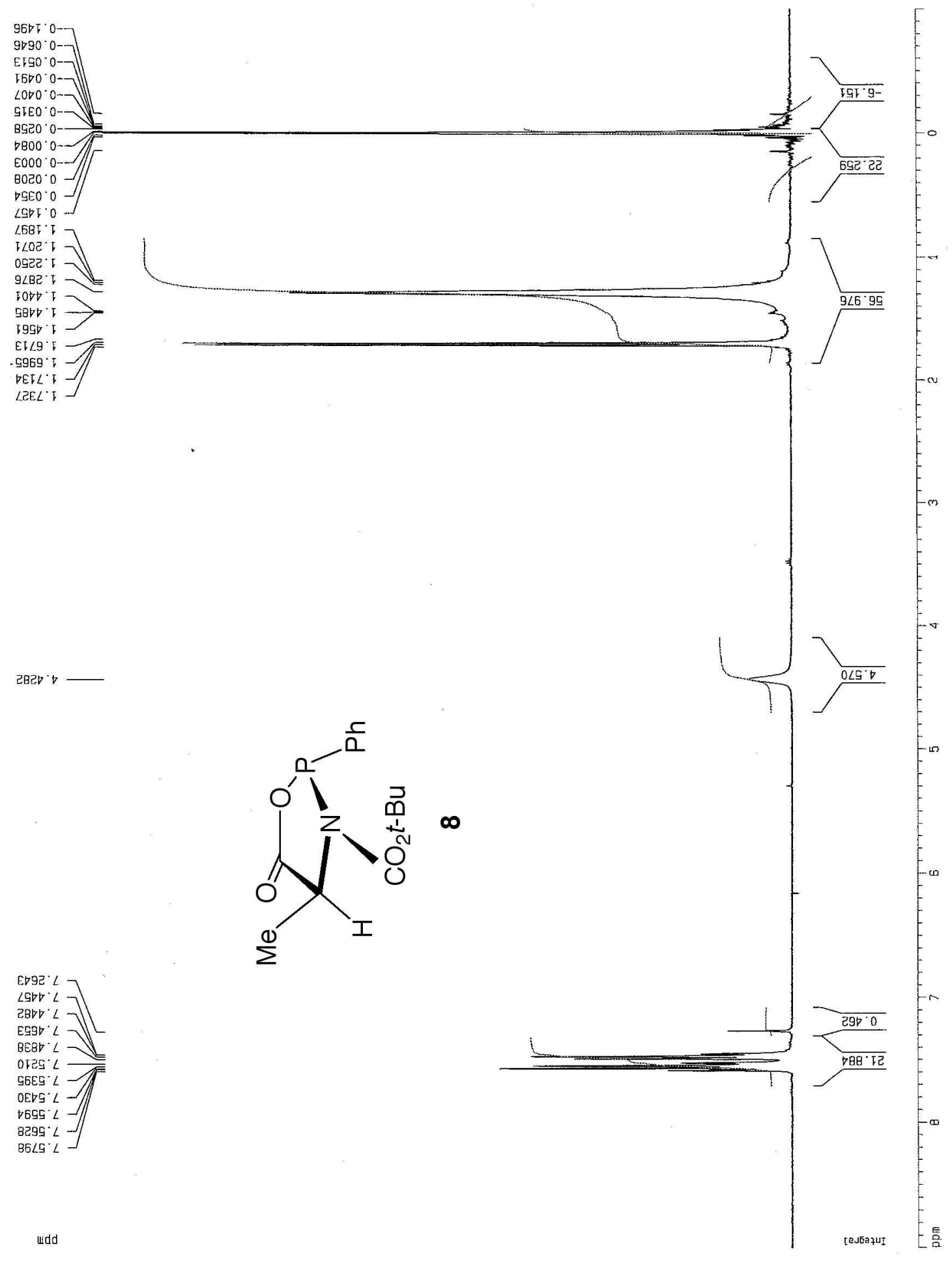



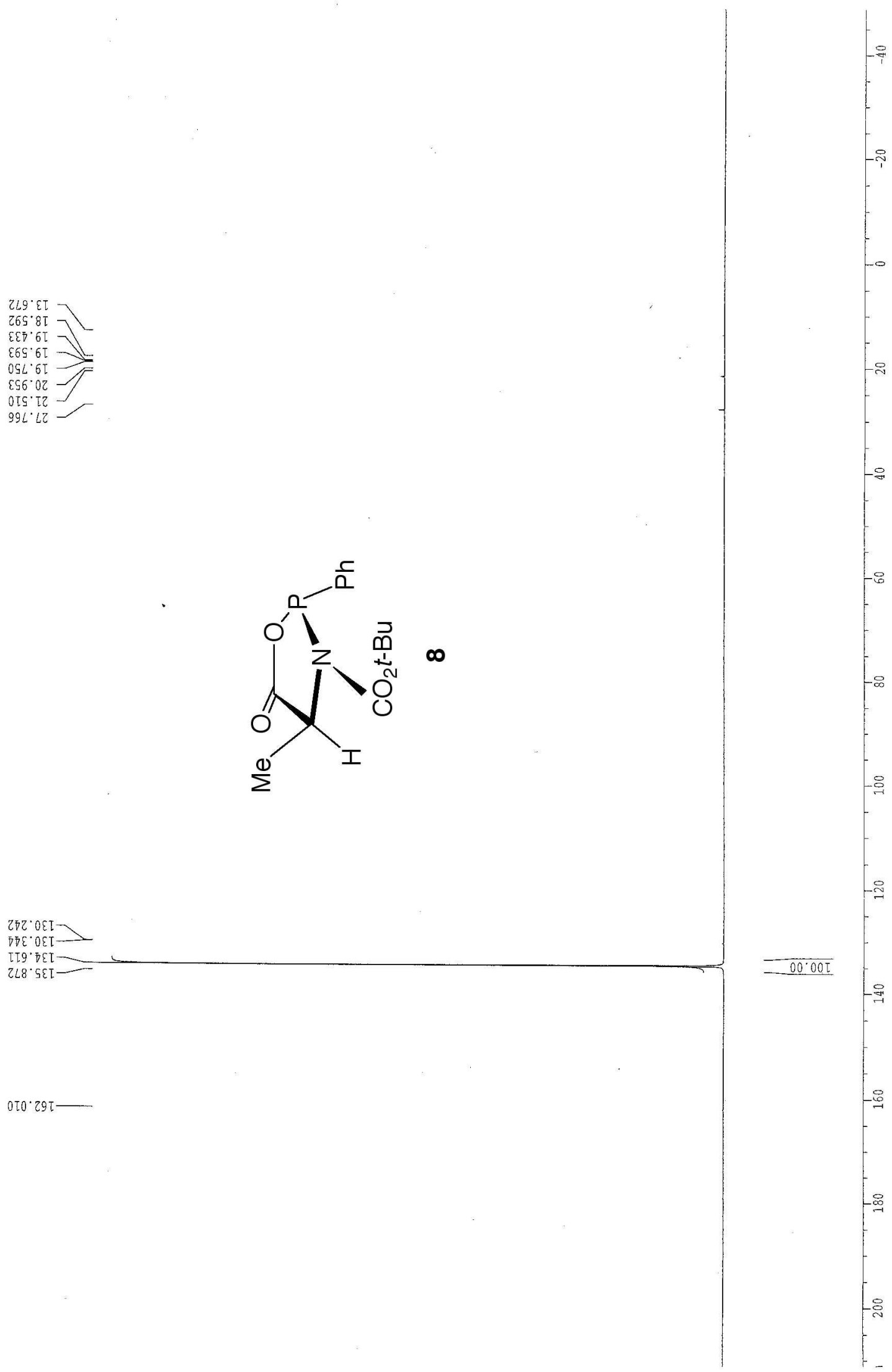

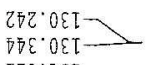

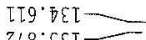

0.0.29ז- 


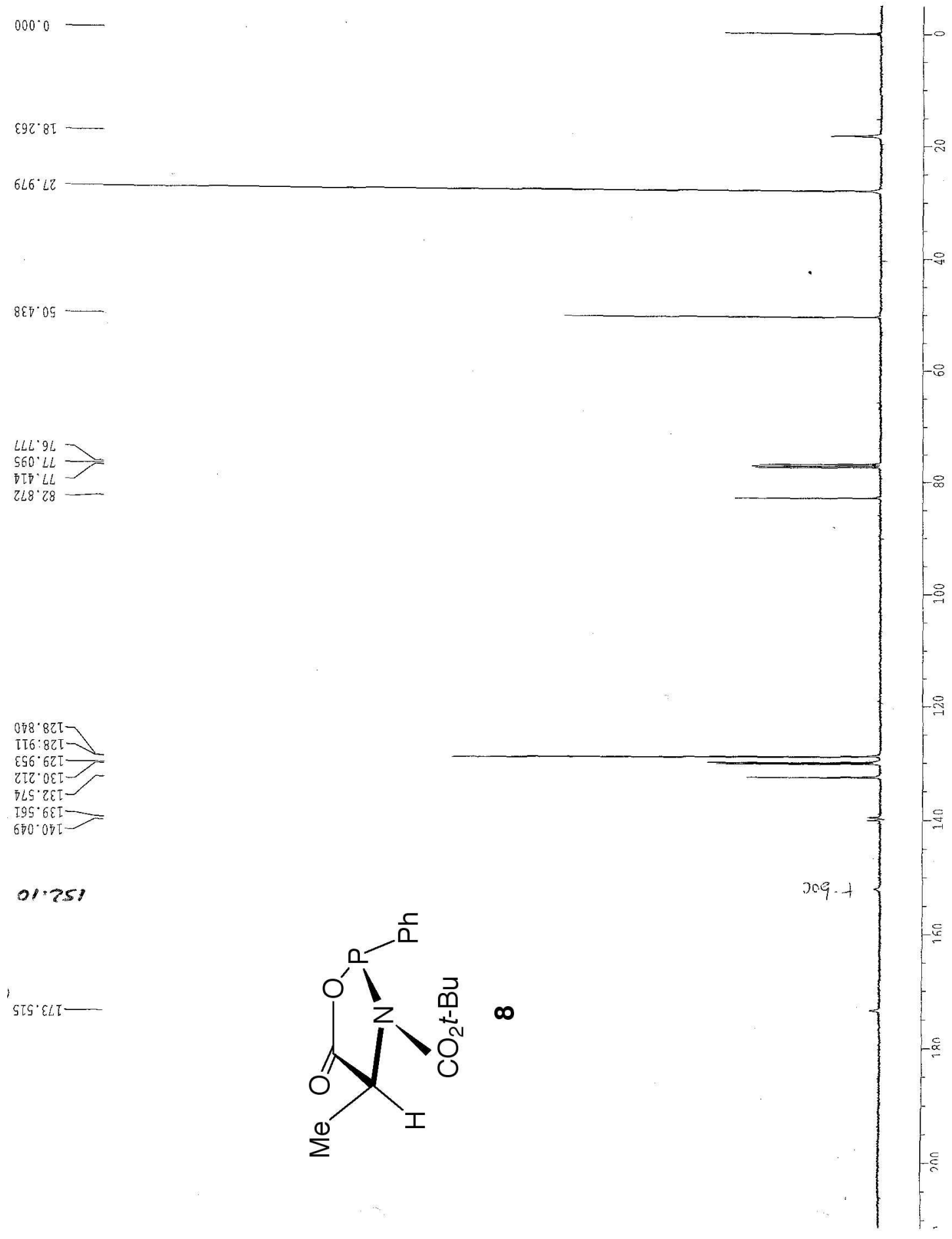




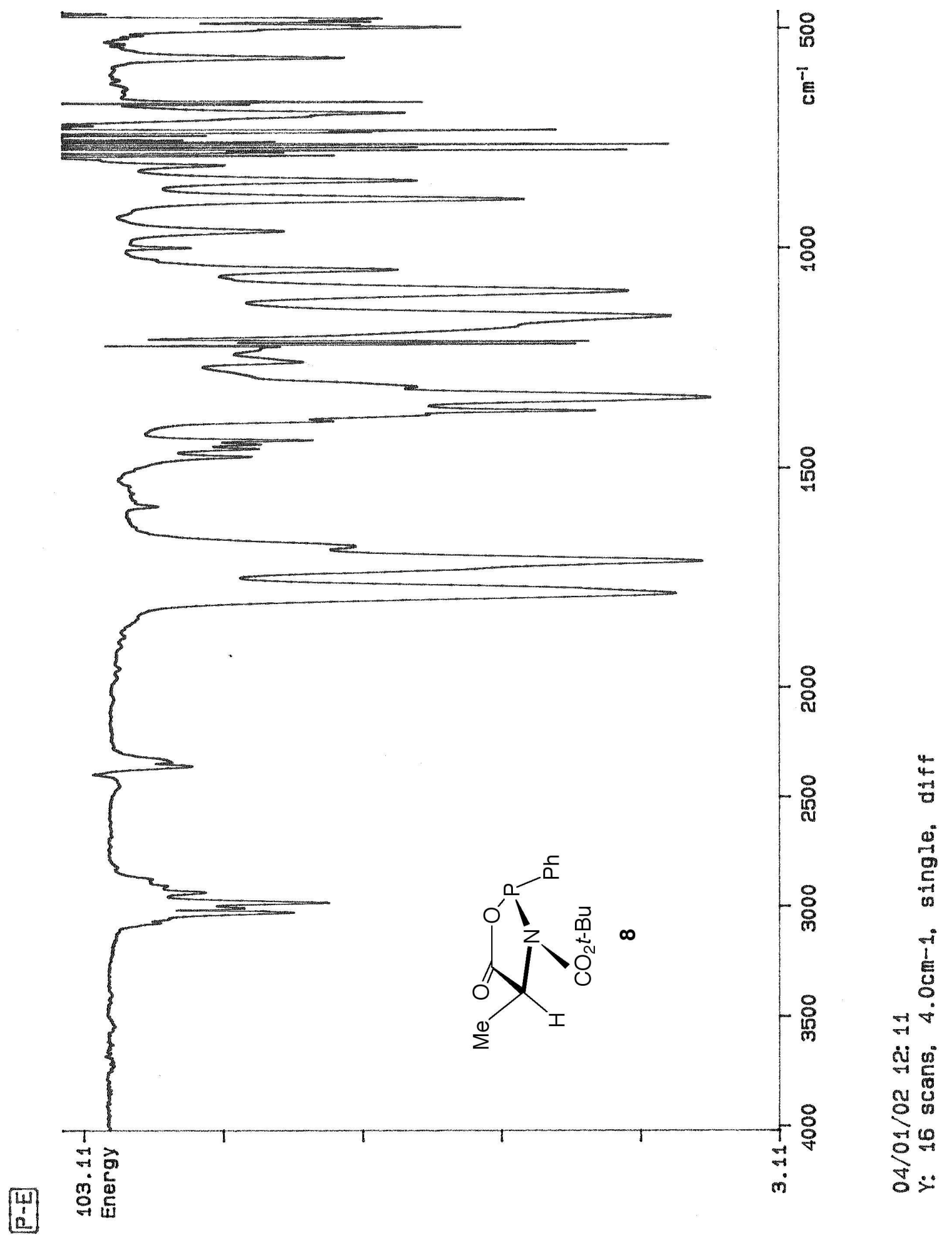




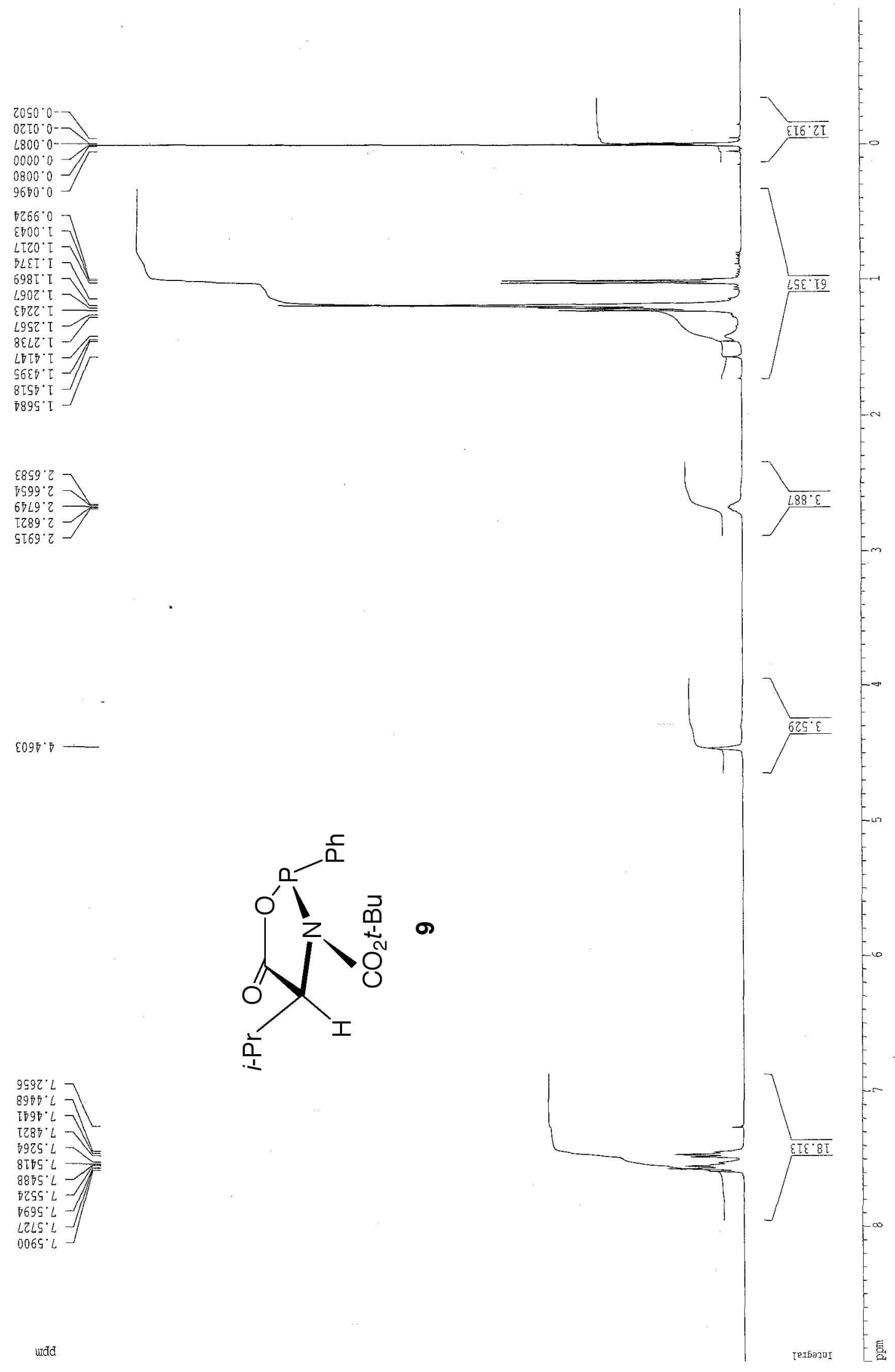


$285 . \angle 2$

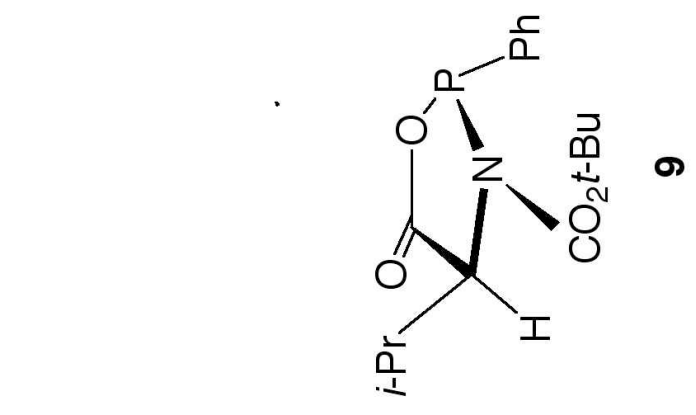

$69 \mathrm{Z}^{\circ} \mathrm{LEI}-$

LOT $8 E I-$

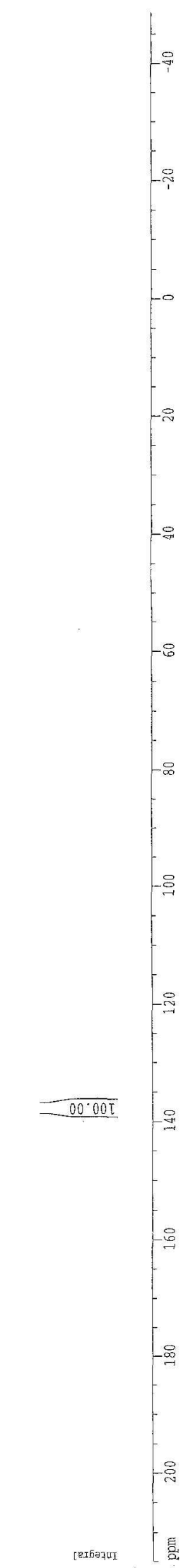

- S13 - 


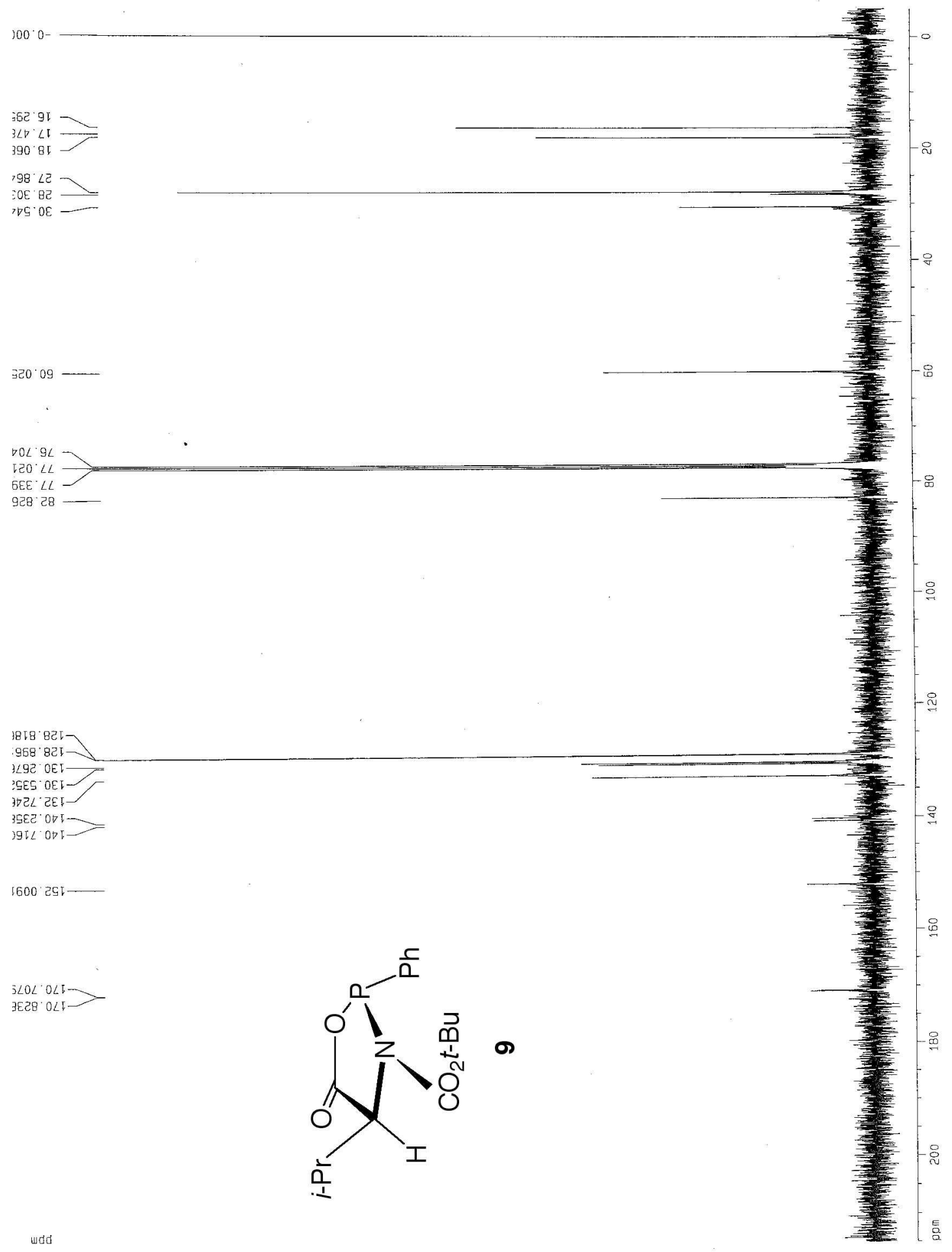




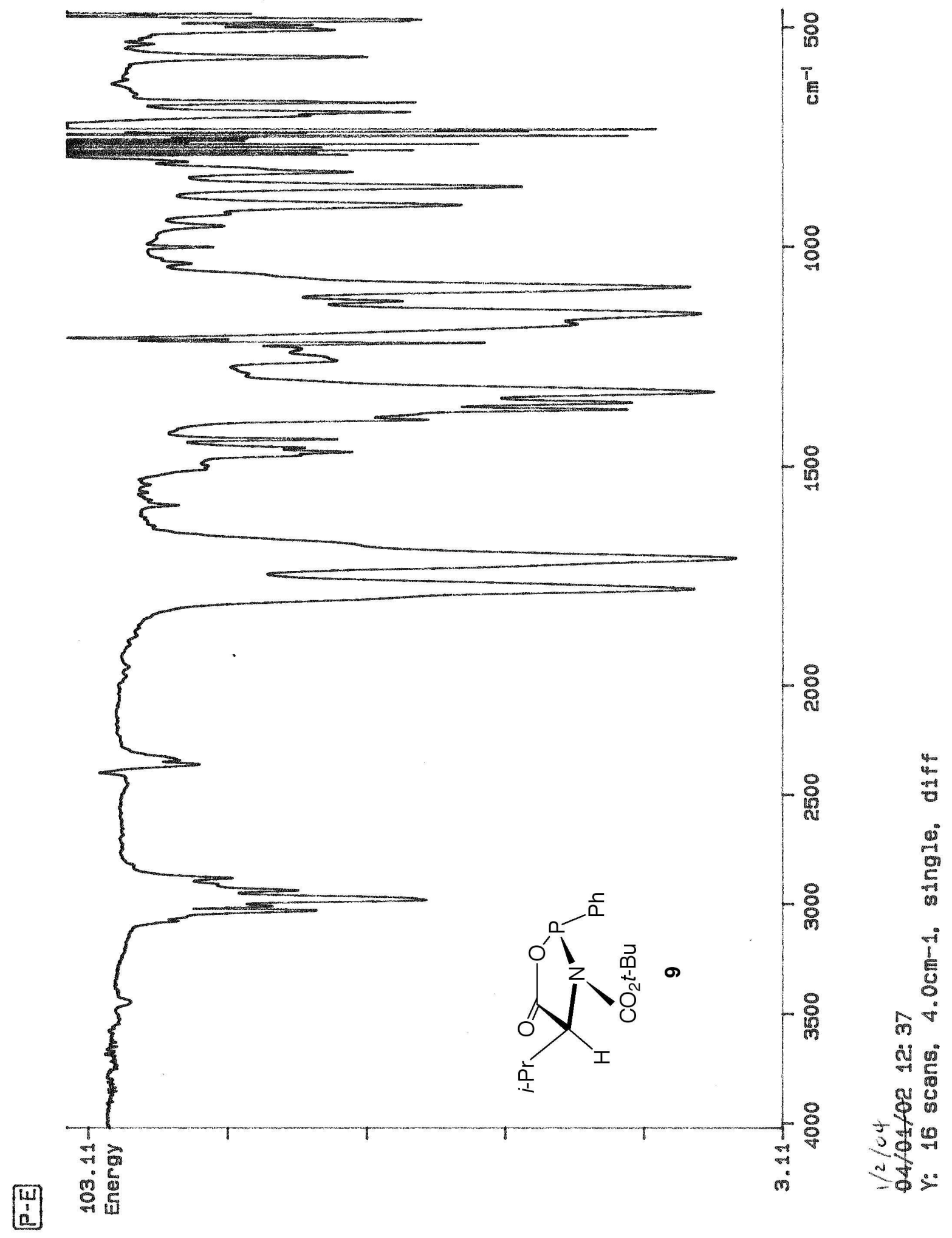

